\title{
Treatment of Hypertriglyceridemia with Omega-3 Fatty Acids: A Systematic Review
}

Amanda Gloria Lewis

Brigham Young University - Provo

Follow this and additional works at: https://scholarsarchive.byu.edu/etd

Part of the Nursing Commons

\section{BYU ScholarsArchive Citation}

Lewis, Amanda Gloria, "Treatment of Hypertriglyceridemia with Omega-3 Fatty Acids: A Systematic Review" (2004). Theses and Dissertations. 161.

https://scholarsarchive.byu.edu/etd/161

This Selected Project is brought to you for free and open access by BYU ScholarsArchive. It has been accepted for inclusion in Theses and Dissertations by an authorized administrator of BYU ScholarsArchive. For more information, please contact ellen_amatangelo@byu.edu. 
TREATMENT OF HYPERTRIGLYCERIDEMIA WITH OMEGA-3 FATTY ACIDS: A SYSTEMATIC REVIEW

by

Amanda Gloria Lewis

\begin{abstract}
A thesis submitted to the faculty of Brigham Young University

in partial fulfillment of the requirement for the degree of

Master of Science
\end{abstract}

College of Nursing

Brigham Young University

August 2004 
Copyright (C) 2003 Amanda Gloria Lewis

All Rights Reserved 


\title{
BRIGHAM YOUNG UNIVERSITY
}

\section{GRADUATE COMMITTEE APPROVAL}

\author{
of a thesis submitted by \\ Amanda Gloria Lewis
}

This thesis has been read by each member of the following graduate committee and by majority vote has been found to be satisfactory.

Date

Date

Date
Sandra Lookinland, Ph.D., R.N.

Chair

Renea L. Beckstrand, Ph.D., R.N., C.C.R.N.

Mary E. Tiedeman, Ph.D., R.N. 


\section{BRIGHAM YOUNG UNIVERSITY}

As chair of the candidate's graduate committee, I have read the project of Amanda Gloria Lewis in its final form and have found that (1) its format, citations, and bibliographical style are consistent and acceptable and fulfill university and college style requirements; (2) its illustrative materials including figures, tables, and charts are in place; and (3) the final manuscript is satisfactory to the graduate committee and is ready for submission to the university library.

Date

Accepted for the College
Sandra Lookinland, Ph.D., R. N.

Chair, Graduate Committee

Mary Williams, Ph.D., R.N.

Graduate Coordinator

Elaine S. Marshall, Ph.D., R.N.

Dean, College of Nursing 


\begin{abstract}
TREATMENT OF HYPERTRIGLYCERIDEMIA WITH

OMEGA-3 FATTY ACIDS: A SYSTEMATIC REVIEW
\end{abstract}

\author{
Amanda Gloria Lewis \\ College of Nursing \\ Masters of Science
}

Purpose: To 1) critically appraise available randomized controlled trials (RTCs) addressing the efficacy of long-chain $\omega-3$ fatty acids as a secondary prevention agent of hypertriglyceridemia, and 2) make recommendations for clinical practice.

Data Sources: All RCTs identified from several databases from 1993-2003 were reviewed by two independent reviewers who extracted data from each study and used the previously tested Boyack and Lookinland Methodological Quality Index (MQI) to determine study quality.

Results: Ten studies reported long-chain $\omega-3$ fatty acids to be effective in the treatment of hypertriglyceridemia. The average decrease in triglycerides (TG) was $29 \%$, total cholesterol $\left(\mathrm{T}_{\mathrm{C}}\right) 11.6 \%$, very low density lipoprotein (VLDL) $30.2 \%$, and low-density lipoprotein (LDL) $32.5 \%$. One study found LDLs to increase by $25 \%$. The average increase in high-density lipoprotein (HDL) was $10 \%$. The overall average MQI score was 
$36 \%(26 \%-54 \%)$. Many of the RCTs had serious shortcomings including short duration, lack of a power analysis, no intention to treat analysis, no report of blind assessment of outcome, and lack of dietary control as a confounding variable.

Conclusions/Implications: Overall study methodology was weak. Although the evidence supporting the use of long-chain $\omega-3$ fatty acids in the secondary prevention of hypertriglyceridemia is reasonably strong, until there are larger RCTs of stronger methodological quality, it is not recommended to treat hypertriglyceridemia with $\omega-3$ fatty acid supplementation in lieu of lipid lowering medications.

Key Words: Long-chain $\omega-3$ fatty acids, eicosapentaenoic acid (EPA), docosahexaenoic acid (DHA), hypertriglyceridemia, hyperlipidemia, systematic review, critical appraisal, alpha linolenic acid, $\omega-6$ fatty acids 


\section{Acknowledgments}

I would like to take this opportunity to express my thanks and appreciation to those who have supported my efforts and made this possible. First, thank to my wonderful and supportive husband, Christopher, for his patience and willingness to help me fulfill my dreams. Without his love and continued encouragement, this would not have been possible. Secondly, thanks to my parents and family for instilling in me the desire to become better and for teaching me of the importance of education.

Also, thanks to my chair, Dr. Sandra Lookinland for her countless hours of encouragement, explanations, and proofreading. And gratitude for my other committee members, Renea L. Beckstrand, and Mary E. Tiedeman for their effort and diligence in making this possible.

I would also like to thank my Heavenly Father for providing so many opportunities for both physical and spiritual growth. He has strengthened me during the times when I thought I could go no further. Without Him, none of this would have been possible. 


\section{Table of Contents}

Acceptance Page................................................................................... iv

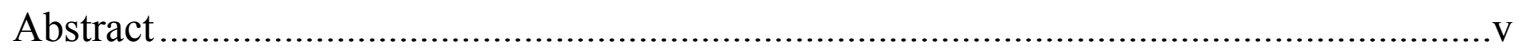

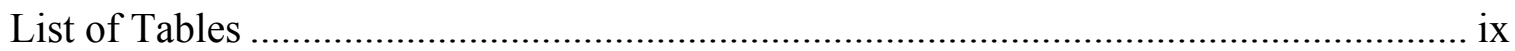

Manuscript: Treatment of Hypertriglyceridemia: with Omega-3 Fatty Acids: A

Systematic Review...................................................1

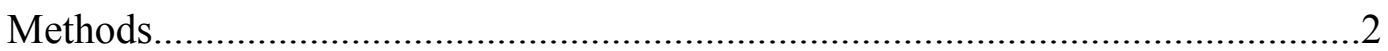

Identification of Studies ...................................................................2

Inclusion/Exclusion Criteria ................................................................

Data Extraction .........................................................................

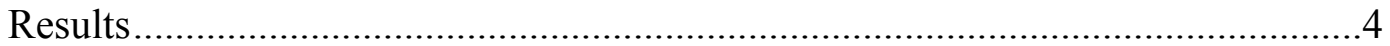

Study Characteristics ...............................................................

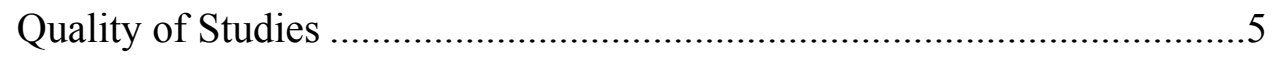

Patient Characteristics.......................................................................

Treatment Characteristics .............................................................6

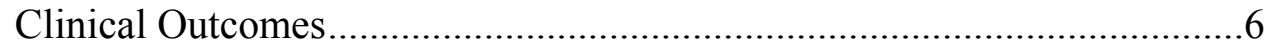

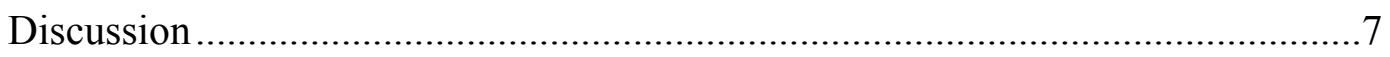

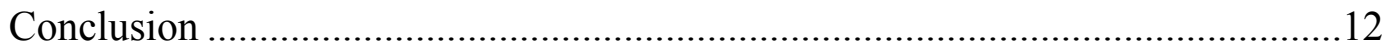

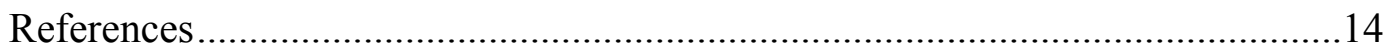


List of Tables

Table 1. Boyack and Lookinland Methodological Quality Index..................................19

Table 2. General Characteristics of Studies of $\Omega-3$ Fatty Acids for Treatment of

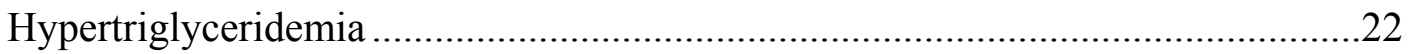

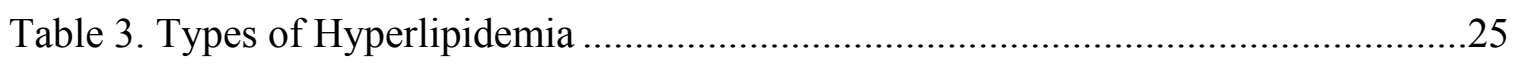

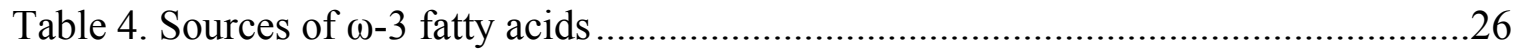


Coronary heart disease (CHD), the leading cause of death among men and women of all ages, has been estimated to affect 12.4 million people in the United States (American Heart Association [AHA], 2000; National Health and Nutrition Examination Surveys, 2002). Identified risk factors for CHD include elevated total cholesterol $\left(\mathrm{T}_{\mathrm{C}}\right)$ and low-density lipoprotein (LDL) levels, while a high level of high-density lipoprotein (HDL) has been shown to be cardioprotective. High levels of triglycerides (TG) have recently been reported as a risk factor for CHD independent of the HDL level (Fruchart \& Duriez, 2002; Gotto, 2002).

Women typically have lower $\mathrm{T}_{\mathrm{C}}$ levels than men until they reach menopause. After menopause $T_{C}$ levels begin to climb until the levels actually exceed those of men (National Health and Nutrition Examination Surveys, 2002). Recent evidence suggests that the relative risk of cardiovascular disease for women with hypertriglyceridemia is higher than for men $(\mathrm{RR}=1.75$ vs. 1.30). Even after accounting for HDL levels, men and women with elevated TG have a significantly higher risk for CHD (Austin, 1998).

The combination of high TG and low HDL levels associated with insulin resistance contribute substantially to CHD. The cluster of symptoms identified as insulin resistance includes borderline high blood glucose levels, hypertension, increased uric acid levels, and central obesity. If individuals with insulin resistance have a $\mathrm{T}_{\mathrm{C}}$ level considered borderline by the National Cholesterol Education Program Adult Treatment Panel III guidelines, they are not categorized as being at higher risk for CHD (Fruchart \& Duriez, 2002).

The goals of hyperlipidemia management remain primary and secondary prevention of CHD. Current treatment includes diets low in saturated fat and cholesterol, 
exercise, and medications such as statins, niacin, cholesterol absorption inhibitors, bile acid sequestrants, and a derivative of fibric acid (gemfibrozil). Beginning in the late 1970s, preliminary research suggested that long chain omega-3 ( $\omega-3)$ fatty acids prevented CHD. The two long chain $\omega-3$ fatty acids that are thought to have cardioprotective effects are eicosapentaenoic acid (EPA) and docosahexaenoic acid (DHA). Unlike $\omega-6$ fatty acids, EPA and DHA lower postprandial lipemia and prevent the lowering of HDL. EPA also lowers $\mathrm{T}_{\mathrm{C}}$ and $\mathrm{TG}$ levels by preventing LDL and TG synthesis in the liver (Harper \& Jacobson, 2001).

Several randomized controlled trials (RCTs) and observational studies reported a decline in TG levels when long chain $\omega-3$ fatty acids were consumed (Harper \& Jacobson, 2001). However, questions remain regarding their use to treat mild to moderate hypertriglyceridemia. Much of the debate centers on the effectiveness of $\omega$-3 fatty acid supplements as opposed to dietary intake of $\omega-3$ fatty acids and the recommended dose of the supplement. Therefore, the purposes of this systematic review are to evaluate the evidence available on long chain $\omega$-3 fatty acids in secondary prevention of hypertriglyceridemia in otherwise healthy individuals, determine the best treatment options, and make recommendations for clinical practice.

Methods

\section{Identification of Studies}

An electronic search was conducted to identify studies from January 1994 to February 2003 in the following databases: EMBASE, MANTIS, Biosis Previews, Science Search, International Pharmaceutical Abstracts, MEDLINE, PubMed, CINAHL, and the Cochrane Library. The search terms used were: eicosapentaenoic acid, EPA, 
docosahexaenoic acid, DHA, $\omega-3$ fatty acids, adult, human, randomized controlled trial, hyperlipidemia, and hypertriglyceridemia. The search was limited to studies published in English. Reference lists of identified articles were searched for additional studies that had been missed. Nine randomized controlled trials were found that matched the search criteria. Contact persons for each of the identified studies were sent a complete list of studies via letter or email and were asked to identify any studies not yet published or not included in the list. One month was allowed for a response. Six of the contacts did not respond to the request. One additional study was identified through contact correspondence (Mori et al., 2000). A list of excluded articles is available from the authors by request.

\section{Inclusion/Exclusion Criteria}

For inclusion in the review study subjects must have had TG levels greater than $150 \mathrm{mg} / \mathrm{dL}$ and/or $\mathrm{T}_{\mathrm{C}}$ greater than $200 \mathrm{mg} / \mathrm{dL}$. Studies were included if the $\omega-3$ fatty acids EPA and/or DHA were ingested in doses greater than or equal to $3 \mathrm{~g} / \mathrm{d}$. All types of hyperlipidemia were included in this review because, in most instances, subjects were not classified by type. Studies were excluded if the subjects had secondary hypertriglyceridemia, known CHD including hypertension, a strong family history of CHD, were part of an ethnic population associated with higher incidences of CHD, had diabetes mellitus or fasting blood sugar levels greater than $130 \mathrm{mg} / \mathrm{dL}$, hypothyroidism, were smokers, alcohol abusers, used hormone replacement therapy for control of menopausal symptoms, or used statins or gemfibrozil as treatment options. 


\section{Data Extraction}

The Boyack and Lookinland Methodological Quality Index (MQI) (Boyack, Lookinland, \& Chasson, 2002) was used to evaluate the quality of the studies included in the review (Table 1). The tool evaluates the strength of the study's design, methods, and analysis. Each study was scored by two independent reviewers (A. L., and S. L.), differences were settled, and consensus was reached by referring to the original study. Overall inter-rater reliability was $r=0.92$. In order to score an article, the information provided in the study was compared with the MQI tool and each item was scored. The final score for an individual study was presented as a percentage. The percentage was found by taking the study's total score and dividing it by the total possible score.

Some study results of lipid levels were reported in $\mathrm{mmol} / \mathrm{L}$. When this occurred, the values in $\mathrm{mmol} / \mathrm{L}$ were divided by the conversion factor 0.0259 for cholesterol values and 0.0113 for TG values to convert the values to $\mathrm{mg} / \mathrm{dL}$ to allow for the comparison of studies (American Medical Association, 2000).

Results

\section{Study Characteristics}

A total of 10 RCTs were identified from the medical and nutritional literature. Three of the 10 studies involved multiple sites (Borthwick, 1998; Harris et al., 1997; Mackness et al, 1994). Although one study was conducted in the United States, most research on $\omega-3$ fatty acids took place in other countries (Australia, Canada, Italy, Norway, Portugal, and the United Kingdom). All of the study designs were RCTs with one using a crossover trial (Calabresi, Donati, Pazzucconi, Sirtori, \& Franceschini, 2000). The length of the studies ranged from 4 to 16 weeks. 
A weakness in all of the studies was a lack of a power analysis. None had a duration longer than 16 weeks, making it difficult to determine the effectiveness of longterm treatment. None of the studies were long enough to be able to report the long-term health outcomes of acute cardiac event prevention, but rather focused on surrogate lipid measures.

Although all the studies reported a decrease in TG, none controlled for diet which could be a major confounding variable if participants in the studies consumed large amounts of $\omega-3$ fatty acids in their diet. Only one of the studies had their participants follow the National Cholesterol Education Program Step I diet while monitoring compliance (Harris et al., 1997).

\section{Quality of Studies}

Each study received a quality score from the Boyack and Lookinland MQI that ranged from $26 \%$ to $54 \%$ out of a possible $100 \%$ (Table 2 ). The average total MQI for the 10 studies was $36 \%$. The higher the score the more closely it matched the standards of the quality index and the higher its methodological soundness. No minimum score was necessary to be included in this review.

\section{Patient Characteristics}

A total of 606 people were studied overall with $83 \%$ being male $(n=505)$. Sample sizes ranged from 14 to 234 with no ethnic minorities included. In the majority of cases the type of hyperlipidemia was not identified. There are seven basic types of hyperlipidemia (Table 3), including types I through V, secondary hypertriglyceridemia, and familial lecithin cholesterol acyltransferase deficiency (Beers \& Berkow, 1999). 


\section{Treatment Characteristics}

Pronova Biocare (Oslo, Norway), the manufacturer of Omacor and K-85, provided funding for five of the six studies that used their products. Other $\omega-3$ preparations included those from Croda Chemicals (Laidlaw \& Holub, 2003), Fish Oil Test Materials Program (Mori et al., 2000), and Hebron (Silva et al., 1996). Dosages of $\omega-3$ fatty acids ranged from $3.4-4$ g per day either as combinations of DHA and EPA or DHA and EPA separately. One study examined the effects of DHA and EPA and varying doses of gamma-linolenic acid (Laidlaw \& Holub, 2003). Another study used a crossover design with Omacor and thus had no placebo (Calabresi et al., 2000). The placebos used in the remaining studies were corn oil (6), soya oil (1), and olive oil (1).

\section{Clinical Outcomes}

All studies except Silva et al. (1996) reported significant decreases in TG levels when study participants were treated with $\omega-3$ fatty acids in dosages of greater than $3.4 \mathrm{~g}$ per day. However, participants included in Silva et al. were consuming fish meals more than six times per week and thus had a significant dietary source of $\omega-3$ fatty acids. The average decrease in TG levels in the studies that found a significant change was $29 \%$ (range $=16 \%-45 \%)$. In the three studies that looked at $\mathrm{T}_{\mathrm{C}}$ the average decrease was $9.3 \%$ (Grimsgaard, Bønaa, Hansen, \& Nordøy, 1997; Harris et al., 1997; Laidlaw \& Holub, 2003). However, seven studies found that EPA and DHA had no significant effect on $T_{C}$ levels (Borthwick, 1998; Chan et al., 2003; Goodfellow, Bellamy, Ramsey, Jones, \& Lewis, 2000; Laidlaw \& Holub; Mackness et al., 1994; Mori et al., 2002; Silva et al.). LDL decreased $11.3 \%$ in one study (Laidlaw \& Holub). However, three studies found LDL to increase significantly (Calabresi et al., 2000; Harris et al.; Mori et al.) by an 
average of $21.6 \%$ (range $=8 \%-32 \%)$, while others found no significant change in LDL (Calabresi et al.; Chan et al.; Goodfellow et al.; Grimsgaard et al.; Laidlaw \& Holub; Mackness et al.; Silva et al.). Mori et al. reported an 8\% rise in LDL with DHA but not EPA. Very low density lipoprotein (VLDL) decreased by $27 \%($ range $=18 \%-33 \%)$ in five studies that used VLDL as an outcome measure (Chan et al.; Calabresi et al.; Grimsgaard et al.; Harris et al.; Mackness et al.). Some studies reported significant increases in HDL of 9.2\% (range $=4 \%-13 \%$ ) (Harris et al.; Grimsgaard et al.; Laidlaw \& Holub) while others found EPA and DHA had no significant effect on HDL levels (Borthwick; Calabresi et al.; Chan et al.; Goodfellow et al.; Mackness et al.; Silva et al.)

\section{Discussion}

Although all of the studies found a significant decrease in TG, the average quality index score of $36 \%$ indicates that the studies were of relatively low quality. However, the average overall score to determine the effectiveness of $\omega-3$ fatty acids in this review is comparable to the MQI score recently reported in a study examining the effectiveness of using garlic to treat elevated lipid levels (Alder, Lookinland, Berry, \& Williams, 2003). Many of the same methodological flaws reported by Alder et al., were seen here as well. These included small sample sizes, a lack of a power analysis, and a lack of control for confounding variables such as fish intake. Additionally, all of the studies were of such a short duration (range 4-16 weeks) that it was impossible to evaluate the effectiveness of long-term $\omega$-3 fatty acid supplementation on hypertension and CHD prevention. However, Harris (1996) reported that continued supplementation with $\omega-3$ fatty acids resulted in lowering TG even after 7 years of treatment. 
Studies would have received higher MQI scores if more information on treatment concealment and on blind assessment of outcomes was provided and limitations and biases were reported. None of the studies did a power analysis before undertaking the study. Without a power analysis it would be difficult to determine if negative findings were truly negative or whether a type II error was made. Biases can occur without concealment of treatment since the researchers may know the study groups to which participants were assigned.

Practitioners plan treatment options based upon findings of drug efficacy on longterm health outcomes. Although $\omega-3$ fatty acids have been shown to decrease TG in a primarily white male population, the question remains, are the findings generalizable to women and ethnic minorities? On-line resources are available to calculate CHD risk based upon TG and other known cardiac risk factors. One such risk calculator provides an estimate of risk for developing CHD over a 10-year period (National Heart, Lung, and Blood Institute, 2002). The tool takes into account age, gender, $\mathrm{T}_{\mathrm{C}}, \mathrm{HDL}$ cholesterol, smoker, and systolic blood pressure. A more inclusive risk calculator for CHD, based on gender, age, LDL, HDL, TG, systolic blood pressure, smoking history, diabetes mellitus, and family history of myocardial infarction calculates the risk of developing CHD over a 10 year period (International Task Force for Prevention of Coronary Heart Disease, n.d.). These risk calculators could be used to guide the practitioner in identifying patients who are at an increased risk of developing CHD in order to institute preventative therapies.

None of the studies addressed possible confounding variables by controlling for diet during the study. A diet low in saturated fats and high in $\omega-3$ fatty acids is the first step in the treatment of patients with increased lipid levels (National Cholesterol 
Education Program Expert Panel, 2002). While it is very costly to strictly control diet during the course of a study, it is impossible to isolate the efficacy of $\omega-3$ fatty acids if subjects are consuming significant amounts of dietary $\omega-3$ fatty acids. It is important to mention that when testing the effectiveness of $\omega-3$ fatty acids in real life clinical situations, the practitioner has no control over an individual patient's diet. When analyzing future studies evaluating the efficacy of $\omega-3$ fatty acids, the reader must evaluate the extent of dietary control, power analysis, intention to treat analysis, and reporting of biases and flaws in the study.

Although the underlying mechanism of action of $\omega-3$ fatty acids remains unknown, studies have shown that their effects are dose related (Carroll \& Roth, 2002; Sanders, 1991). Chan et al. (2003) postulated that $\omega-3$ fatty acids reduce TG by lowering the production of VLDL apolipoprotein B, thus decreasing cholesterol synthesis in the liver. The decreased synthesis of VLDL results in a lower level in the blood and more VLDL converted into LDL. Others (Calabresi et al., 2000) believe that $\omega-3$ fatty acids decrease TG by altering lipoprotein metabolism in the liver and exerting an effect on target lipid genes. When synthesis of TG and VLDL is decreased, the breakdown of intermediate-density lipoprotein (IDL) is also decreased and more IDL particles are converted to LDL. However, since LDL particles are not broken down this may result in a rise in LDL. In patients with type IV and V hyperlipidemias LDL increased as TG decreased with $\omega-3$ fatty acid supplementation (Calabresi et al., 2000; Sanders, 1991).

Large lipid particles, such as chylomicrons and VLDL, cannot pass through the endothelial wall and are deposited in the blood vessel intima. Because small particles such as small VLDL particles, VLDL remnants, and IDLs, can easily pass through the 
endothelial barrier they are considered highly atherogenic (Fruchart \& Duriez, 2002). It is known that small VLDL particles are easily converted to LDL (Sanders, 1991).

Although TG can be lowered by dietary intake of long chain $\omega$-3 fatty acids, the amount needed to achieve therapeutic levels depends on the type of fish consumed (Table 4). Although there are other non-fish sources of $\omega-3$ fatty acids, studies have not confirmed the benefits of non-fish oil sources. In the typical American diet the total intake of $\omega-3$ fatty acids is $\approx 1.6 \mathrm{~g} / \mathrm{d}$ (Kris-Etherton, Harris, \& Appel, 2002). The majority of this $(\approx 1.4 \mathrm{~g} / \mathrm{d})$ is in the form of $\alpha$-linolenic acid, which largely comes from canola and soybean oil. The American Heart Association recommends consuming two fish meals per week with emphasis on fatty fish (i.e., salmon, herring, and mackerel), but discourages fried fish because of its high trans-fatty acid and low $\omega-3$ fatty acid content. The World Health Organization and other countries (Canada, Sweden, United Kingdom, Australia, and Japan) have recommended the consumption of 0.3 to $0.5 \mathrm{~g} / \mathrm{d}$ of EPA and DHA. It has been recommended that patients with CHD increase their dose to $1 \mathrm{~g} / \mathrm{d}$ of DHA and EPA (Kris-Etherton et al.).

The amount of fish needed to lower TG levels can be difficult to consume because of the high cost of fish, the risk of environmental toxins with certain species of fish, and the vast amounts needed to achieve a decrease in TG levels. Omega-3 fatty acid supplements are considered a food supplement by the Food and Drug Administration, and different preparations contain varying amounts of DHA and EPA. The most common $\omega-3$ fatty acid supplements contain $180 \mathrm{mg}$ of EPA and $120 \mathrm{mg}$ of DHA in each capsule (Kris-Etherton et al., 2002). In order for patients with CHD to consume $\approx 1 \mathrm{~g} / \mathrm{d}$ of DHA and EPA three capsules per day would be needed. More concentrated preparations of 
DHA and EPA can be found in the European market. Omacor is one such preparation, but it is not currently available in the United States. In 2003, Pronova Biocare, the maker of Omacor, is applying for a new drug application with the FDA.

The efficacy of $\omega-3$ fatty acid supplementation also depends heavily on the type of hyperlipidemia being treated. For those with type II or III hyperlipoproteinemia, fish oil supplements will slightly decrease TG and VLDL, and have no effect on LDL or $\mathrm{T}_{\mathrm{C}}$ levels. In those with type IV or V, however, a significant decrease in TG will result in a rise in $\mathrm{LDL}$ and little or no change in $\mathrm{T}_{\mathrm{C}}$ with possible slight or no increases in HDL (Sanders, 1991).

Omega-6 fatty acids are the fatty acids consumed in largest amounts by most Americans. Some of the common sources of $\omega-6$ fatty acids are walnuts, brazil nuts, canola, corn, evening primrose, sesame, safflower, soya, and sunflower oil (Willett, 2001). They reduce $T_{C}$, decrease cholesterol deposits in vessels, and cause a slight decrease in TG levels (Kris-Etherton, 1999). Although the majority of studies reviewed used an $\omega-6$ fatty acid as placebo, this was not considered a methodological flaw since this is the major dietary source of fatty acids in the United States.

Other benefits have been associated with the intake of $\omega-3$ fatty acids. A strong negative relationship has been found between fish intake or supplementation and risk of sudden death (Albert et al., 1998; Siscovick et al., 1995) and coronary heart disease (Djousse et al., 2001). These findings have been confirmed in healthy men as well (Albert et al., 2002). A lower risk $(\mathrm{RR}=0.4)$ of acute myocardial infarction (AMI) was reported in both sexes (Landmark et al., 1998). In those who suffered an AMI, the infarct size was smaller (Guallar et al., 1999). 
While the current evidence suggests that supplementation of $\omega-3$ fatty acids in doses greater than $3.4 \mathrm{~g}$ in Caucasian males with hypertriglyceridemia results in a decrease in TG, there are still important questions that need to be answered before practitioners can safely recommend them to their patients. Future large RCTs need to focus on $\omega-3$ fatty acid supplementation in approximate doses of $4 \mathrm{~g} / \mathrm{d}$ in women and minorities with high TG levels since insufficient evidence exists to support practice recommendations in these groups. Future studies should stratify by types of hyperlipidemia to control for LDL and $\mathrm{T}_{\mathrm{C}}$ since $\omega$-3 fatty acids have differential effects based on the hyperlipidemia classification.

\section{Conclusion}

All of the recent studies (1994-2003) that evaluated the effect of long-chain $\omega-3$ fatty acids on hypertriglyceridemia have methodological flaws. None performed a power analysis before recruiting participants, which resulted in underpowered studies. There was no control for confounding variables such as dietary intake of $\omega-3$ fatty acids, no report on double blind assessment of outcomes, and no intention to treat analysis. The absence of these critical elements made it difficult to draw a conclusion about the efficacy of the use of long-chain $\omega-3$ fatty acids in the treatment of hypertriglyceridemia. The Consolidated Standards of Reporting Trials (CONSORT) guidelines should be followed as future studies are developed to improve study reporting (Moher, Schulz, \& Altman, 2001). Although the evidence supporting the use of long-chain $\omega-3$ fatty acids in the secondary prevention of hypertriglyceridemia is fairly strong, until there are larger RCTs with longer durations the authors cannot recommend the use of long-chain $\omega-3$ 
fatty acids in the treatment of secondary hypertriglyceridemia in lieu of lipid lowering medications. 


\section{References}

Albert, C. M., Campos, H., Stampfer, M. J., Ridker, P. M., Manson, J. E., Willett, W. C., et al. (2002). Blood levels of long-chain n-3 fatty acids and the risk of sudden death. The New England Journal of Medicine, 346, 1113-1118.

Albert, C. M., Hennekens, C. H., O’Donnell, C. J., Ajani, U. A., Carey, V. J., Willett, W. C. et al. (1998). Fish consumption and risk of sudden cardiac death. The Journal of the American Medical Association, 279, 23-28.

Alder, R., Lookinland, S., Berry, J. A., \& Williams, M. (2003). A systematic review of the effectiveness of garlic as an anti-hyperlipidemic agent. Journal of the American Academy of Nurse Practitioners, 15, 120-129.

American Heart Association. (2000). 2001 Heart and stroke statistical update. Dallas, TX: American Heart Association.

American Medical Association. (2000). Système international (SI) conversion factors for selected laboratory components. The Journal of the American Medical Association, 283, 134-135.

Austin, M. A. (1998). Plasma triglyceride as a risk factor for cardiovascular disease. The Canadian Journal of Cardiology, 14, (Suppl. B), 14B-17B.

Beers, M. H., \& Berkow, R. (Eds.). (1999). The Merck Manual of Diagnosis and Therapy (17 $7^{\text {th }}$ ed.). [electronic version] Whitehouse Station, NJ: Merck. Retrieved Feb 17, 2003, from http://www.merck.com/pubs/mmanual/

Borthwick, L. J. (1998). The effects of an omega-3 ethyl ester concentrate on blood lipid concentrations in patients with hyperlipidaemia. Clinical Drug Investigation, 15, 397-404. 
Boyack, M., Lookinland, S., \& Chasson, S. (2002). Efficacy of raloxifene for treatment of menopause: A systematic review. Journal of the American Academy of Nurse Practitioners, 14, 150-165.

Calabresi, L., Donati, D., Pazzucconi, F., Sirtori, C. R., \& Franceschini, G. (2000). Omacor in familial combined hyperlipidemia: Effects on lipids and low density lipoprotein subclasses. Atherosclerosis, 148, 387-396.

Carroll, D. N., \& Roth, M. T. (2002). Evidence for the cardioprotective effects of omega3 fatty acids. The Annals of Pharmacotherapy, 36, 1950-1956.

Chan, D. C., Watts, G. F., Mori, T. A., Barrett, P. H. R., Redgrave, T. G., \& Beilin, L. J. (2003). Randomized controlled trial of the effect of n-3 fatty acid supplementation on the metabolism of apolipoprotein B-100 and chylomicron remnants in men with visceral obesity. The American Journal of Clinical Nutrition, 77, 300-307.

Djoussé, L., Pankow, J. S., Eckfeldt, J. H., Folsom, A. R., Hopkins, P. N., Province, M. A., et al. (2001). Relation between dietary linolenic acid and coronary artery disease in the national heart, lung, and blood institute family heart study. The American Journal of Clinical Nutrition, 74, 612-619.

Fruchart, J. C., \& Duriez, P. (2002). HDL and triglyceride as therapeutic targets. Current Opinion in Lipidology, 13, 605-616.

Goodfellow, J., Bellamy M. F., Ramsey, M. W., Jones, C. J. H., \& Lewis, M. J. (2000). Dietary supplementation with marine omega-3 fatty acids improve systemic large artery endothelial function in subjects with hypercholesterolemia. Journal of the American College of Cardiology, 35, 265-270. 
Gotto, A. M. (2002). High-density lipoprotein cholesterol and triglycerides as therapeutic targets for preventing and treating coronary artery disease. American Heart Journal, 144, (Suppl. 6), S33-S42.

Grimsgaard, S., Bønaa, K. H., Hansen, J. B., \& Nordøy, A. (1997). Highly purified eicosapentaenoic acid and docosahexaenoic acid in humans have similar triacylglycerol-lowering effects but divergent effects on serum fatty acids. The American Journal of Clinical Nutrition, 66, 649-659.

Guallar, E., Aro, A., Jimenez, F. J., Martin-Moreno, J. M., Salminen, I., van't Veer, P., et al. (1999). Omega-3 fatty acids in adipose tissue and risk of myocardial infarction: The EURAMIC study. Arteriosclerosis, Thrombosis, and Vascular Biology, 19, 1111-1118.

Harris, W. S. (1996). N-3 fatty acids and lipoproteins: Comparison of results from human and animal studies. Lipids, 31, 243-252.

Harris, W. S., Ginsberg, H. N., Arunakul, N., Shachter, N. S., Windsor, S. L., Adams, M., et al. (1997). Safety and efficacy of Omacor in severe hypertriglyceridemia. Journal of Cardiovascular Risk, 4, 385-391.

Harper, C. R., \& Jacobson, T. A. (2001). The fats of life: The role of omega-3 fatty acids in the prevention of coronary heart disease. Archives of Internal Medicine, 161, $2185-2192$.

International Task Force for Prevention of Coronary Heart Disease. (n.d.). Coronary risk assessment. Retrieved March 12, 2003, from http:/www.chdtaskforce.de/assessment.htm 
Kris-Etherton, P. M., (1999). Monounsaturated fatty acids and risk of cardiovascular disease. Circulation, 100, 1253-1258.

Kris-Etherton, P. M., Harris, W. S., \& Appel, L. J. (2002). Fish consumption, fish oil, omega-3 fatty acids, and cardiovascular disease. Circulation, 106, 2747-2757.

Laidlaw, M., \& Holub, B. J. (2003). Effects of supplementation with fish oil-derived n-3 fatty acids and $\gamma$-linolenic acid on circulating plasma lipids and fatty acid profiles in women. The American Journal of Clinical Nutrition, 77, 37-42.

Landmark, K., Abdelnoor, M., Urdal, P., Kilhovd, B., Dorum, H. P., Borge, N., et al. (1998). Use of fish oils appears to reduce infarct size as estimated from peak creatine kinase and lactate dehydrogenase activities. Cardiology, 89, 94-102.

Mackness, M. I., Bhatnagar, D., Durrington, P. N., Prais, H., Haynes, B., Morgan J., et al. (1994). Effects of a new fish oil concentrate on plasma lipids and lipoproteins in patients with hypertriglyceridaemia. European Journal of Clinical Nutrition, 48, 859-865.

Mori, T. A., Burke, V., Puddey, I. B., Watts, G. F., O’Neal, D. N., Best, J. D., et al. (2000). Purified eicosapentaenoic and docosahexaenoic acids have differential effects on serum lipids and lipoproteins, LDL, particle size, glucose, and insulin in mildly hyperlipidmic men. The American Journal of Clinical Nutrition, 71, 1085-1094.

Moher, D., Schulz, K. F., \& Altman, D. (2001). The CONSORT statement: Revised recommendations for improving the quality of reports of parallel-group randomized trials. The Journal of the American Medical Association, 285, 19871991. 
National Cholesterol Education Program Expert Panel. (2002). Detection, evaluation, and treatment of high blood cholesterol in adults (adult treatment panel III). Retrieved March 12, 2003, from

http://www.nhlbi.nih.gov/guidelines/cholesterol/atp3full.pdf

National Health and Nutrition Examination Surveys. (2002). Serum cholesterol levels among persons 20 years of age and over, according to sex, age, race, and Hispanic origin: United States, 1960-62, 1971-74, 1976-80, and 1988-94. Retrieved April 17, 2003, from http://www.cdc.gov/nchs/data/hus/tables/2002/02hus069.pdf

National Heart, Lung, and Blood Institute. (2002). Risk assessment tool for estimating your 10-year risk of having a heart attack (myocardial infarction and coronary death). Retrieved March 12, 2003, from http://hin.nhlbi.nih.gov/atpiii/calculator.asp

Sanders, T. A. B. (1991). Influence of $\omega 3$ fatty acids on blood lipids. World Review of Nutrition and Dietetics, 66, 358-366.

Siscovick, D. S., Raghunathan, T. E., King, I., Weinmann, S., Wicklund, K. G., Albright, J., et al. (1995). Dietary intake and cell membrane levels of long-chain n-3 polyunsaturated fatty acids and the risk of primary cardiac arrest. The Journal of the American Medical Association, 274, 1363-1367.

Silva, J. M., Souza, I., Silva, R., Tavares, P., Teixeira, F., \& Silva, P. S. (1996). The triglyceride lowering effect of fish oils is affected by fish consumption. International Journal of Cardiology, 57, 75-80.

Willett, W. C. (2001). Eat, drink, and be healthy. New York: Simon \& Schuster. 
Table 1. Boyack and Lookinland Methodological Quality Index

\begin{tabular}{|c|c|c|c|c|c|}
\hline & & $\begin{array}{l}\text { Possible } \\
\text { Points } \\
\end{array}$ & $\begin{array}{l}\text { Item } \\
\text { Score } \\
\end{array}$ & $\begin{array}{l}\text { Sub- } \\
\text { Total }\end{array}$ & Total/\% \\
\hline & Methods : & & & & \\
\hline 1. & Multi-center/multi-national study & & & & \\
\hline & a. Yes & 2 & & & \\
\hline & b. No & 0 & & & \\
\hline 2. & Study funded by drug company: & & & & \\
\hline & a. No & 1 & & & \\
\hline & b. Yes/Not stated & 0 & & & \\
\hline 3. & Eligibility criteria: & & & & \\
\hline & a. Included all eligible subjects with \# excluded/reasons given & 2 & & & \\
\hline & b. \# excluded or reasons for failure/exclusion not explicitly given & 1 & & & \\
\hline & c. Selected patients/eligibility not described & 0 & & & \\
\hline 4. & Power analysis: & & & & \\
\hline & a. Power of $80 \%$ or greater and achieved sample size & 4 & & & \\
\hline & b. Underpowered due to loss of follow-up & 1 & & & \\
\hline & c. Power analysis not done & 0 & & & \\
\hline 5. & Sample equivalency addressed: & & & & \\
\hline & a. Yes & 2 & & & \\
\hline & b. Addressed but no p value given & 1 & & & \\
\hline & b. No & 0 & & & \\
\hline 6. & Randomization: & & & & \\
\hline & a. Use of random numbers table & 2 & & & \\
\hline & b. Other method used & 1 & & & \\
\hline & c. Not reported & 0 & & & \\
\hline 7. & Method of blinding subjects to treatment reported: & & & & \\
\hline & a. Yes & 2 & & & \\
\hline & b. Stated but unclear & 1 & & & \\
\hline & c. No & 0 & & & \\
\hline 8. & Blind assessment of outcome: & & & & \\
\hline & a. Yes & 3 & & & \\
\hline & b. Partial & 1 & & & \\
\hline & c. No & 0 & & & \\
\hline 9. & Concealment of treatment schedule: & & & & \\
\hline & a. Adequately concealed & 4 & & & \\
\hline & b. Inadequate concealed/Unclear & 0 & & & \\
\hline 10. & Intention to treat analysis & & & & \\
\hline & a. Yes & 2 & & & \\
\hline & b. No & 0 & & & \\
\hline 11. & Treatment arm differences: & & & & \\
\hline & a. Placebo and 1 parallel treatment & 2 & & & \\
\hline & b. Placebo or parallel treatment only & 1 & 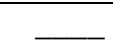 & & \\
\hline
\end{tabular}


Treatment of Hypertriglyceridemia 20

\begin{tabular}{|c|c|c|c|c|c|}
\hline & & $\begin{array}{l}\text { Possible } \\
\text { Points }\end{array}$ & $\begin{array}{l}\text { Item } \\
\text { Score } \\
\end{array}$ & $\begin{array}{l}\text { Sub- } \\
\text { Total }\end{array}$ & Total/\% \\
\hline \multirow[t]{6}{*}{12.} & Duration of therapy: & & & & \\
\hline & a. $\geq 3$ years & 4 & & & \\
\hline & b. $\geq 2$ years & 3 & & & \\
\hline & c. $\geq 1 \mathrm{yr}$ & 2 & & & \\
\hline & d. $\geq 6$ months & 1 & & & \\
\hline & e. $<6$ months & 0 & & & \\
\hline \multirow{11}{*}{13.} & Intervention: & & & & \\
\hline & a. Dosing regimen (frequency/dose) explicitly described & & & & \\
\hline & 1. Yes & 1 & & & \\
\hline & 2. No & 0 & & & \\
\hline & & & & & \\
\hline & b. Explicit description of co-intervention & & & & \\
\hline & 1. Yes & 1 & & & \\
\hline & 2. No & 0 & & & \\
\hline & 3. Not applicable & N/A & & & \\
\hline & & & & & \\
\hline & Outcomes: & & & & \\
\hline \multirow{4}{*}{14.} & Lost to follow up: & & & & \\
\hline & a. $>80 \%$ follow up in each group & 3 & & & \\
\hline & b. Less than $80 \%$ follow up & 1 & & & \\
\hline & c. Subjects not accounted for & 0 & & & \\
\hline \multirow{6}{*}{15.} & Withdrawals reported individually by group: & & & & \\
\hline & a. Described \# and reasons for withdrawal & 3 & & & \\
\hline & b. Described either number or reason for withdrawal & 2 & & & \\
\hline & c. Described withdrawals globally but not by group & 1 & & & \\
\hline & d. Described neither number nor reason for withdrawal & 0 & & & \\
\hline & e. Not applicable & N/A & & & \\
\hline \multirow{3}{*}{16.} & Adherence to nrotocol renorted- & & & & \\
\hline & a. Yes & 1 & & & \\
\hline & b. No & 0 & & & \\
\hline \multirow{5}{*}{17.} & Long term health outcome reported: & & & & \\
\hline & a. Yes & 4 & & & \\
\hline & c. No & 0 & & & \\
\hline & & & & & \\
\hline & Treatment Effect: & & & & \\
\hline \multirow{3}{*}{18.} & Statictical methods renorted. & & & & \\
\hline & a. Yes & 3 & & & \\
\hline & b. No & 0 & & & \\
\hline \multirow{4}{*}{19.} & Maior endpoints reported: & & & & \\
\hline & a. Stat significant/negative findings (sufficient power) $>50 \%$ variables & 2 & & & \\
\hline & b. Trend toward significance (sufficient power) & 1 & & & \\
\hline & c. Negative findings (insufficient power) & 0 & & & \\
\hline \multirow{4}{*}{20.} & Findings of adverse effects reported: & & & & \\
\hline & a. Significant difference ( $\mathrm{p}$ value) between treatment and control group & 2 & & & \\
\hline & b. Adverse effects only without $\mathrm{p}$ value addressed & 1 & & & \\
\hline & c. Not reported & 0 & & & \\
\hline
\end{tabular}




\begin{tabular}{|c|c|c|c|c|c|}
\hline & & $\begin{array}{l}\text { Possible } \\
\text { Points }\end{array}$ & $\begin{array}{l}\text { Item } \\
\text { Score }\end{array}$ & $\begin{array}{l}\text { Sub- } \\
\text { Total }\end{array}$ & Total/\% \\
\hline \multirow[t]{3}{*}{21.} & Confidence interval between means of treatment groups reported: & & & & \\
\hline & a. Yes & 3 & & & \\
\hline & b. No & 0 & & & \\
\hline \multirow[t]{11}{*}{22.} & Range of CI & & & & \\
\hline & a. If using mean diff/proportions, includes value of 0 & & & & \\
\hline & 1. No & 3 & & & \\
\hline & 2. Yes & 0 & & & \\
\hline & 3. Not applicable & N/A & & & \\
\hline & OR & & & & \\
\hline & b. If using OR or RR, includes value of 1 & & & & \\
\hline & 1. No & 3 & & & \\
\hline & 2. Yes & 0 & & & \\
\hline & 3. Not applicable & N/A & & & \\
\hline & Magnitude of reported differences: & & & & \\
\hline \multirow[t]{10}{*}{23.} & Effect size & & & & \\
\hline & a. Large $(>0.80)$ & 4 & & & \\
\hline & b. Moderate $(0.20-0.79)$ & 2 & & & \\
\hline & c. Small $(<0.20)$ & 1 & & & \\
\hline & d. Unable to calculate & 0 & & & \\
\hline & OR & & & & \\
\hline & Proportionate differences $>20 \%$ & & & & \\
\hline & a. Yes & 4 & & & \\
\hline & b. Available on some variables & 2 & & & \\
\hline & c. No or unable to calculate & 0 & & & \\
\hline \multirow[t]{5}{*}{24.} & Quantitative boundary explicit & & & & \\
\hline & a. Yes & 4 & & & \\
\hline & b. No & 0 & & & \\
\hline & c. Not applicable & N/A & & & \\
\hline & Summary: & & & & \\
\hline \multirow[t]{3}{*}{25.} & Statement of financial disclosure/competing interests & & & & \\
\hline & a. Yes & 2 & & & \\
\hline & b. No & 0 & & & \\
\hline \multirow[t]{4}{*}{26.} & Limitations/biases reported: & & & & \\
\hline & a. Yes & 2 & & & \\
\hline & b. Partially & 1 & & & \\
\hline & b. No & 0 & & & \\
\hline
\end{tabular}


Table 2. General Characteristics of Studies of $\Omega-3$ Fatty Acids for Treatment of Hypertriglyceridemia

\begin{tabular}{|c|c|c|c|c|c|c|c|}
\hline Author & Subjects & Duration & Exclusion Criteria & Patient Characteristics & Study Purpose/Outcomes & Treatment & MQI \\
\hline Chan et al., 2003 & $\mathrm{n}=24$ & 6 weeks & $\begin{array}{l}\text { DM, apolipoprotein E2/E2 } \\
\text { genotype, macroproteinuria, } \\
\text { creatinemia }>1.4 \mathrm{mg} / \mathrm{dl} \text {, } \\
\text { hypothyroidism, abnormal liver } \\
\text { enzymes, alcohol consumption }> \\
30 \mathrm{~g} / \mathrm{d}, \mathrm{CVD} \text {, or medications or } \\
\text { agents that affect liver } \\
\text { metabolism }\end{array}$ & $\begin{array}{l}\text { Obese males (waist } \\
\text { circumference }>39.4 \mathrm{in} \text {, } \\
\mathrm{BMI}>29 \text { ) } \\
\mathrm{TG}>106 \mathrm{mg} / \mathrm{dL} \\
\mathrm{T}_{\mathrm{C}}>200 \mathrm{mg} / \mathrm{dL}\end{array}$ & $\begin{array}{l}\text { To determine the efficacy of } \\
\text { Omacor in treating } \\
\text { dyslipidemia in obese men. } \\
\downarrow \text { TG by } 18 \%^{\mathrm{a}} \\
\downarrow \text { VLDL } 33 \%^{\mathrm{a}}\end{array}$ & $\begin{array}{l}\text { Omacor } 3.4 \mathrm{~g} / \mathrm{d} \\
(\mathrm{EPA}+\mathrm{DHA}) \\
\text { vs. Corn oil }\end{array}$ & $37 \%$ \\
\hline $\begin{array}{l}\text { Laidlaw et al., } \\
2003\end{array}$ & $\mathrm{n}=32$ & 4 weeks & $\begin{array}{l}\text { Consumption of fish, borage and } \\
\text { evening primrose oil }\end{array}$ & $\begin{array}{l}\text { Females only } \\
\text { Mean age }=48 \mathrm{yrs} \\
\text { Mean weight }=150 \mathrm{lb} \\
\text { Mean } \mathrm{BMI}=25.5\end{array}$ & $\begin{array}{l}\text { To determine the effects of } \\
\text { GLA, EPA, and DHA on } \\
\text { triglycerides, fatty acid } \\
\text { patterns, and serum } \\
\text { phospholipids. } \\
\\
\downarrow \text { TG } \\
39.7 \%(4: 0) \\
39.2 \%(4: 1) \\
35.4 \%(4: 2)^{\mathrm{a}} \\
\downarrow \text { LDL } \\
11.3 \%(4: 2)^{\mathrm{a}} \\
\uparrow \mathrm{HDL} \\
7 \%(4: 0) \\
10 \%(4: 1)^{\mathrm{a}} \\
\downarrow \text { non-HDL } \mathrm{T}_{\mathrm{C}} \\
5.3 \%(4: 1) \\
14.4 \%(4: 2)^{\mathrm{a}} \\
\downarrow \mathrm{T}_{\mathrm{C}}: \mathrm{HDL} \\
11 \%(4: 0)^{\mathrm{a}} \\
9.6 \%(4: 1)^{\mathrm{a}} \\
14 \%(4: 2)^{\mathrm{d}} \\
14.7 \%(4: 4)^{\mathrm{a}} \\
\downarrow \mathrm{LDL}: \mathrm{HDL} \\
6 \%(4: 1)^{\mathrm{a}} \\
14.8 \%(4: 2)^{\mathrm{e}} \\
19.9 \%(4: 4)^{\mathrm{a}}\end{array}$ & $\begin{array}{l}4 \text { g EPA + DHA } \\
(4: 0) \\
\text { vs. } 4 \text { g EPA + } \\
\text { DHA and } 1 \text { g GLA } \\
(4: 1) \\
\text { vs. } 2 \text { g GLA }(4: 2) \\
\text { vs. } 4 \text { g GLA }(4: 3)\end{array}$ & $38 \%$ \\
\hline
\end{tabular}




\begin{tabular}{|c|c|c|c|c|c|c|c|}
\hline $\begin{array}{l}\text { Calabresi et al., } \\
2000\end{array}$ & $\mathrm{n}=14$ & 8 weeks & $\begin{array}{l}\mathrm{Lp}(\mathrm{a}) \text { concentration }>30 \mathrm{mg} / \mathrm{dl} \text {, } \\
\text { apolipoprotein E2/E2 phenotype, } \\
\text { HRT, } \beta \text {-blockers, or diuretics. }\end{array}$ & $\begin{array}{l}\text { Males \& Females with } \\
\text { FCHL } \\
\text { Mean age }=47 \mathrm{yrs} \text {, } \\
\mathrm{T}_{\mathrm{C}} \text { and } / \text { or } \mathrm{TG}>90^{\circ} \text { than } \\
\text { the general population } \\
\text { Mean } \mathrm{TG}=378 \mathrm{mg} / \mathrm{dL} \\
\text { Not overweight } \\
\text { Low fat ( } 30 \% \text { calories) diet } \\
\geq 6 \text { months. }\end{array}$ & $\begin{array}{l}\text { To determine the efficacy of } \\
\text { Omacor in lowering lipids } \\
\text { in patients with FCHL. } \\
\downarrow \text { TG } 21 \% \text { vs. placebo } \\
\downarrow \text { TG } 27 \% \text { vs. baseline }{ }^{a} \\
\downarrow \text { VLDL } 29 \% \text { vs. placebo } \\
\downarrow \text { VLDL } 18 \% \text { vs. baseline }{ }^{a} \\
\uparrow \text { LDL } 25 \% \text { vs. placebo } \\
\uparrow \text { LDL } 21 \% \text { vs. baseline }{ }^{1}- \\
\text { not significant }\end{array}$ & $\begin{array}{l}\text { Omacor } 3.4 \mathrm{~g} / \mathrm{d} \\
(\mathrm{EPA}+\mathrm{DHA}) \text { in a } \\
\text { crossover trial }\end{array}$ & $34 \%$ \\
\hline $\begin{array}{l}\text { Goodfellow et al., } \\
2000\end{array}$ & $\mathrm{n}=30$ & 16 weeks & $\begin{array}{l}\text { Active or recent ex-smoker, DM, } \\
\text { HTN, hx of coronary, cerebral, } \\
\text { or PV disease, HRT, taking } \\
\text { vasoactive medications, } \\
\text { vitamins, anti-oxidants, or fish } \\
\text { oils. }\end{array}$ & $\begin{array}{l}\text { Males \& Females } \\
\text { Age range }=38-69 \mathrm{yrs} \\
\mathrm{T}_{\mathrm{C}}>250 \mathrm{mg} / \mathrm{dL} \text {, } \\
\text { Low fat diet for } 3 \text { months }\end{array}$ & $\begin{array}{l}\text { To determine the efficacy of } \\
\omega-3 \text { fatty acids in treating } \\
\text { hypercholesterolemia and } \\
\text { improving large artery } \\
\text { endothelial function. } \\
\downarrow \text { TG } 16 \% \text { a }\end{array}$ & $\begin{array}{l}\text { K-85 (85\% EPA \& } \\
\text { DHA) + } 4 \text { IU Vit E } \\
\text { (Omacor) vs. } \\
\text { Corn oil }\end{array}$ & $37 \%$ \\
\hline Mori, et al., 2000 & $\mathrm{n}=56$ & 6 weeks & $\begin{array}{l}\text { Symptomatic CHD within the } \\
\text { previous } 3 \text { months, DM, liver } \\
\text { and renal disease. NSAID, } \\
\text { antihypertensive, or lipid } \\
\text { therapy. Consumption of }<210 \\
\text { ml alcohol/wk. }\end{array}$ & $\begin{array}{l}\text { Males } \\
\text { Age range }=20-65 \mathrm{yrs} \\
\mathrm{BMI} \text { range }=25-30 \\
\mathrm{~T}_{\mathrm{c}}>231 \mathrm{mg} / \mathrm{dL} \\
\mathrm{TG}>160 \mathrm{mg} / \mathrm{dL}\end{array}$ & $\begin{array}{l}\text { To determine the } \\
\text { differential effects of EPA } \\
\text { and DHA on lipids, } \\
\text { lipoproteins, glucose, and } \\
\text { insulin. } \\
\downarrow \text { TG } 20 \% \text { DHA group }{ }^{j} \\
\downarrow \text { TG } 18.4 \% \text { EPA group } \\
{ }^{k} \\
\uparrow \text { LDL } 8 \% \text { DHA group }\end{array}$ & $\begin{array}{l}\text { EPA, } 4 \text { g/d vs. } \\
\text { DHA, } 4 \text { g/d vs. } \\
\text { Olive oil } 4 \mathrm{~g} / \mathrm{d}\end{array}$ & $32 \%$ \\
\hline Borthwick, 1998 & $\mathrm{n}=55$ & 12 weeks & $\begin{array}{l}177 \mathrm{mg} / \mathrm{dL} \geq \mathrm{TG} \geq 885 \mathrm{mg} / \mathrm{dL}, \\
\mathrm{T}_{\mathrm{C}} \leq 200 \mathrm{mg} / \mathrm{dL} \\
\text { Weight change }>2.2 \mathrm{lb} / \mathrm{wk} \\
\text { Unstable lipid values }\end{array}$ & $\begin{array}{l}\text { Males \& Females } \\
\text { Mean age }=54 \mathrm{yrs} \\
\text { Mean weight }=170 \mathrm{lb} .\end{array}$ & $\begin{array}{l}\text { To determine the effects of } \\
\text { Omacor on lipid value in } \\
\text { patients with } \\
\text { hyperlipidemia. } \\
\downarrow \text { TG } 28 \% \text { e }\end{array}$ & $\begin{array}{l}\text { Omacor }(4 \mathrm{~g} \text { EPA } \\
+\mathrm{DHA} / \mathrm{d}) \mathrm{vs} \text {. } \\
\text { Corn oil } 4 \mathrm{~g} / \mathrm{d}\end{array}$ & $42 \%$ \\
\hline $\begin{array}{l}\text { Grimsgaard et al., } \\
1997\end{array}$ & $\mathrm{n}=234$ & 7 weeks & $\begin{array}{l}\text { Smokers, prescription or } \\
\text { nonprescription drug users, DM, } \\
\mathrm{CV} \text {, liver and renal disease, } \\
\text { bleeding disorders, and } \\
\text { alcoholism. }\end{array}$ & $\begin{array}{l}\text { Males } \\
\text { Age range }=35-55 \mathrm{yrs} \\
\mathrm{T}_{\mathrm{C}}<367 \mathrm{mg} / \mathrm{dL} \\
\mathrm{TG}<442 \mathrm{mg} / \mathrm{dL} \\
\text { Consumption of }<4 \text { fish } \\
\text { dishes/ week }\end{array}$ & $\begin{array}{l}\text { To determine the effects of } \\
\text { EPA and DHA on lipids, } \\
\text { apolipoproteins, and serum } \\
\text { phospholipid fatty acid } \\
\text { composition. } \\
\downarrow \text { TG } 26 \% \text { DHA group }\end{array}$ & $\begin{array}{l}\text { EPA, } 4 \text { g/d vs. } \\
\text { DHA, } 4 \text { g/d vs. } \\
\text { Corn oil, } 4 \mathrm{~g} / \mathrm{d}\end{array}$ & $54 \%$ \\
\hline
\end{tabular}


Treatment of Hypertriglyceridemia 24

\begin{tabular}{|c|c|c|c|c|c|c|c|}
\hline & & & & & $\begin{array}{l}\downarrow \text { TG 21\% EPA group } \\
{ }^{\mathrm{d}} \\
\downarrow \mathrm{T}_{\mathrm{C}} 2.5 \% \text { EPA group } \\
\uparrow \\
\uparrow \text { HDL } 4 \% \text { DHA group }^{\mathrm{c}}\end{array}$ & & \\
\hline Harris et al., 1997 & $\mathrm{n}=42$ & 16 weeks & $\begin{array}{l}\text { Cold water fish }>1 / \text { week, Type } \\
\text { III hyperlipidemia, MI }<6 \text { mo } \\
\text { before, ALT }>3 \times \text { normal, } \\
\text { Fasting glucose }>200 \mathrm{mg} / \mathrm{dL} \text {, } \\
\text { Creatinine }>2 \mathrm{mg} / \mathrm{dL}, \text { Platelet } \\
\text { count }<60 \times 10^{9} / 1 \text {, Hemoglobin } \\
<10 \mathrm{~g} / \mathrm{dL}, \text { Pregnant, or breast } \\
\text { feeding, } 2 \text { alcohol drinks/d } \\
\text { Clinically significant disease }\end{array}$ & $\begin{array}{l}\text { Males \& Females } \\
\text { Age range }=18-75 \mathrm{yr} \\
\text { TG } 492-2000 \mathrm{mg} / \mathrm{dL}\end{array}$ & $\begin{array}{l}\text { To determine the efficacy } \\
\text { and safety of Omacor in } \\
\text { treating patients with } \\
\text { hypertriglyceridemia. } \\
\downarrow \text { TG } 45 \% \text { e } \\
\downarrow T_{C} 15 \%{ }^{\mathrm{c}} \\
\downarrow \text { VLDL } 32 \% \text { e } \\
\downarrow \mathrm{T}_{\mathrm{C}}: \text { HDL ratio } 20 \%{ }^{\mathrm{f}} \\
\uparrow \mathrm{LDL} 32 \% \mathrm{~h} \\
\uparrow \text { HDL } 13 \% \mathrm{~g}^{\mathrm{g}}\end{array}$ & $\begin{array}{l}\text { Omacor } 4 \mathrm{~g} / \mathrm{d} \\
(\mathrm{EPA}+\mathrm{DHA}) \mathrm{vs.} \\
\text { Corn oil }\end{array}$ & $35 \%$ \\
\hline Silva et al., 1996 & $\mathrm{n}=40$ & 8 weeks & $\begin{array}{l}\text { Hypersensitivity to fish oil } \\
\text { Creatine }>1.5 \mathrm{mg} / \mathrm{dL} \\
\text { Liver or non-atherosclerotic } \\
\text { neurologic diseases, DM, MI or } \\
\text { stroke } \leq 6 \text { months ago } \\
\text { Heart failure, premenopause, } \\
\text { secondary hypercholesterolemia, } \\
>96 \mathrm{~g} \text { alcohol/day }\end{array}$ & $\begin{array}{l}\text { Males \& Females } \\
\text { Age range }=18-70 \mathrm{yr} \\
\mathrm{TG}>200 \mathrm{mg} / \mathrm{dL} \text { or } \\
\text { Mixed hyperlipidemia with } \\
\mathrm{T}_{\mathrm{C}}>200 \mathrm{mg} / \mathrm{dL} \text { and } \\
\mathrm{TG}>200 \mathrm{mg} / \mathrm{dL}\end{array}$ & $\begin{array}{l}\text { To determine the efficacy of } \\
\omega \text {-3 fatty acids and fish } \\
\text { consumption in the } \\
\text { treatment of Portuguese } \\
\text { patients with } \\
\text { hypertriglyceridemia and } \\
\text { mixed hyperlipidemia. } \\
\downarrow \text { TG } 27.8 \%^{\mathrm{m}}-\text { not } \\
\text { significant }\end{array}$ & $\begin{array}{l}\text { Fish oil }(\text { EPA + } \\
\text { DHA, } 3.6 \mathrm{~g} / \mathrm{d}) \text { vs. } \\
\text { Soya oil }\end{array}$ & $26 \%$ \\
\hline $\begin{array}{l}\text { Mackness et al., } \\
1994\end{array}$ & $\mathrm{n}=79$ & 14 weeks & $\begin{array}{l}\text { DM, hypothyroidism, serious } \\
\text { illness in the past } 3 \text { months, } \\
\text { severe concurrent illness, and } \\
\text { drug and alcohol abusers }\end{array}$ & $\begin{array}{l}\text { Males \& Females } \\
\text { Age range }=18-70 \text { yrs } \\
\text { Primary type IIb or IV } \\
\text { hyperlipidemia } \\
\text { TG } 177-885 \mathrm{mg} / \mathrm{dL}, \\
\mathrm{T}_{\mathrm{C}}>200 \mathrm{mg} / \mathrm{dL}\end{array}$ & $\begin{array}{l}\text { To determine the efficacy of } \\
\text { K- } 85 \text { in treating patients } \\
\text { with primary } \\
\text { hypertriglyceridemia. } \\
\downarrow \text { TG } 28 \% \%^{\mathrm{c}} \\
\downarrow \text { VLDL } 24 \% \text { d } \\
\uparrow \text { HDL } 12 \%^{\mathrm{d}}\end{array}$ & $\begin{array}{l}\text { K-85 4g/d vs. } \\
\text { Corn oil } 4 \text { g/d }\end{array}$ & $29 \%$ \\
\hline
\end{tabular}

${ }^{\mathrm{a}} \mathrm{p}<0.05 ;{ }^{\mathrm{b}} \mathrm{p}=0.032 ;{ }^{\mathrm{c}} \mathrm{p}<0.001 ;{ }^{\mathrm{d}} \mathrm{p}<0.01 ;{ }^{\mathrm{e}} \mathrm{p}<0.0001 ;{ }^{\mathrm{f}} \mathrm{p}=0.0013 ;{ }^{\mathrm{g}} \mathrm{p}=0.014 ;{ }^{\mathrm{h}} \mathrm{p}=0.0014 ;{ }^{\mathrm{i}} \mathrm{p}=0.019 ;{ }^{\mathrm{j}} \mathrm{p}=0.003 ;{ }^{\mathrm{k}} \mathrm{p}=0.012 ;{ }^{\mathrm{l}} \mathrm{p}=0.054 ;{ }^{\mathrm{m}}=0.0867$

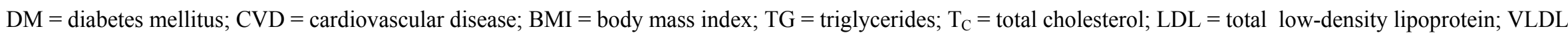
= total very-low-density lipoprotein; $\mathrm{HDL}=$ total high-density lipoprotein; EPA = eicosapentaenoic acid; DHA = docosahexaenoic acid; GLA = gamma-linolenic acid;

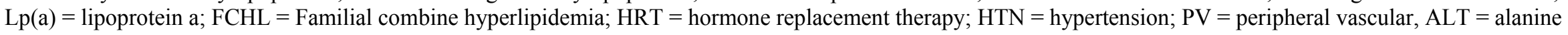
aminotransferase; $\mathrm{MI}=$ myocardial infarction 
Table 3. Types of Hyperlipidemia*

\begin{tabular}{|l|l|}
\hline Type I hyperlipoproteinemia & $\begin{array}{l}\text { A rare disorder characterized by high TG levels and } \\
\text { pancreatitis. }\end{array}$ \\
\hline Type II hyperlipoproteinemia & $\begin{array}{l}\text { Elevation of LDL by either primary or secondary } \\
\text { causes and low TG and VLDL concentrations. } \\
\text { Includes familial hypercholesterolemia, familial } \\
\text { combined hyperlipidemia, defective familial } \\
\text { apolipotrotein B, and polygenic } \\
\text { hypercholesterolemia. }\end{array}$ \\
\hline $\begin{array}{l}\text { Type III, or } \\
\text { dysbetalipoproteinemia }\end{array}$ & $\begin{array}{l}\text { Characteristic xanthomas and premature } \\
\text { atherosclerosis }\end{array}$ \\
\hline Type IV & $\begin{array}{l}\text { Common in middle-aged men with a family history } \\
\text { of variable elevated triglycerides. }\end{array}$ \\
\hline Type V & $\begin{array}{l}\text { A rare disorder distinguished by a faulty clearance of } \\
\text { exogenous and endogenous triglycerides which puts } \\
\text { the person at increased risk for life-threatening } \\
\text { pancreatitis. }\end{array}$ \\
\hline Secondary hypertriglyceridemia & $\begin{array}{l}\text { Most common type; result of another health } \\
\text { condition. }\end{array}$ \\
\hline $\begin{array}{l}\text { Familial lecithin cholesterol } \\
\text { acyltransferase deficiency }\end{array}$ & $\begin{array}{l}\text { A rare disorder that is a result of a deficient enzyme } \\
\text { manifested by severe hypercholesterolemia, } \\
\text { hyperphospholipidemia, and hypertriglyceridemia }\end{array}$ \\
\hline
\end{tabular}

*Adapted from: Beers, M. H., \& Berkow, R. (Eds.). (1999). The Merck Manual of Diagnosis and Therapy (17 ${ }^{\text {th }}$ ed.). [On-line], Available:

http://www.merck.com/pubs/mmanual/ 
Table 4 . Sources of $\omega-3$ Fatty Acids*

\begin{tabular}{|l|c|c|}
\hline & $\begin{array}{c}\text { EPA + DHA content in a } \\
3 \text { oz serving }\end{array}$ & $\begin{array}{c}\text { Amount needed for } \\
\approx 1 \mathrm{~g} / \mathrm{d} \text { of EPA }+ \\
\text { DHA }\end{array}$ \\
\hline Pacific Herring & $1.81 \mathrm{~g}$ & $1.5 \mathrm{~g}$ \\
\hline Sardines & $0.98-1.70 \mathrm{~g}$ & $2-3 \mathrm{~g}$ \\
\hline Trout, farmed rainbow & $0.98 \mathrm{~g}$ & $3 \mathrm{~g}$ \\
\hline Salmon, Atlantic, wild & $0.9-1.56 \mathrm{~g}$ & $2-3.5 \mathrm{~g}$ \\
\hline Trout, wild rainbow & $0.84 \mathrm{~g}$ & $3.5 \mathrm{~g}$ \\
\hline Tuna, white canned in water, drained & $0.73 \mathrm{~g}$ & $4 \mathrm{~g}$ \\
\hline Halibut & $0.4-1.0 \mathrm{~g}$ & $3-7.5 \mathrm{~g}$ \\
\hline Crab, Alaskan King & $0.35 \mathrm{~g}$ & $8.5 \mathrm{~g}$ \\
\hline Mackerel & $0.34-1.57 \mathrm{~g}$ & $2 .-8.5 \mathrm{~g}$ \\
\hline Shrimp, mixed species & $0.27 \mathrm{~g}$ & $11 \mathrm{~g}$ \\
\hline Scallops & $0.17 \mathrm{~g}$ & $17.5 \mathrm{~g}$ \\
\hline
\end{tabular}

*Adapted from Kris-Etherton, P. M., Harris, W. S., \& Appel, L. J. (2002). Fish consumption, fish oil, omega-3 fatty acids, and cardiovascular disease. Circulation, 106, 2747-2757. 